\title{
Commodity fetishism revisited: historical-materialist orientations on art and literature
}

\begin{abstract}
In Sotheby's contemporary art auction last November 2013, avant-garde art confirmed its absorption by the market with the $\$ 104.5$ million sale of Andy Warhol's 1963 "Silver Car Crash (Double Disaster)". In 2007, his "Green Car Crash" sold for \$1.7 million, proof that the aura of the name dictates market value, with the subject or content of the art work adding enough differentia specifica to mark its historical period or milieu. In the past, Francis Bacon's "Three Studies of Lucien Freud" sold for \$142.4 million while Gerhard Richert's abstract “A.B. Courbet” sold for \$26.4 million and Cy Twombly's "Poems to the Sea" (1959 drawings) sold for \$21.6 million (New York Times 2013). Commodification seems to have climaxed in a species of postmodern aesthetics designated "conceptual" and "post-conceptual. Exchange-value (embodied in money as cause) has displaced use-value (now conceived as effect). At the outset, the term "conceptual" art offers a conundrum since it is not clear what concept is referred to, or whether the term designates the artist's intention. A metalepsis seems to have occurred. Art generates the concept (telos; universal significance) instead of the concept (vision or intuition) engendering the performative discursive practice.
\end{abstract}

Keywords: historical, materialist, orientations, art, literature, conundrum, million, pronouncements, planning, recognizable
Volume 2 Issue 6 - 2018

\author{
San Juan $E$ \\ Department of English \& Comparative Literature, University of \\ the Philippines, Philippines
}

Correspondence: San Juan E, Department of English \& Comparative Literature, University of the Diliman, QuezonCity, Philippines, Tel 202 b7924887, Email philesc@gmail.com

Received: March 03, 2018 | Published: November 27, 2018

\section{Introduction}

\section{Postmodern Conceptualism}

As early as 1970, Mel Bochner, one of the practitioners of "conceptual art," questioned the epithet's ambiguity and lack of precision. In any case, the rubric "conceptual art" has been used to cover the works created by artists such as Sol Lewitt, Robert Smithson, Joseph Kosuth, Lawrence Weiner, Bruce Naumann and others during its apogee and crisis in the years 1966-1972. ${ }^{1}$ While Kosuth proposed that conceptual art defines itself by questioning the nature of art, Lewitt posited its essence to be found in "the idea or concept" which becomes "a machine that makes the art" (1967), the concept itself subsuming the planning and decisions that enable the execution of the art-work. Lewitt's pronouncements have become so scriptural that a popular Dictionary of Theories ascribes conceptual art as a "cerebral approach" championed by Lewitt in 1967 as a reaction against postwar formalistic art. Since the concept or idea becomes paramount in the artistic process, the planning and concept are decided beforehand, but the end result is intuitive and without recognizable purpose. ${ }^{2}$

Before venturing further into nomenclature and examples, it might be illuminating to review the field of aesthetics and, with it, the theory of art. Art and aesthetics need to be differentiated, the former dealing with the object produced or created and the latter with the experience and knowledge of the art-object. Ultimately, however, with the postmodern interrogation of the concept of art (in both the ontological and phenomenological senses), the two coalesce in the conceptualist revision. Whether such a result is helpful in clarifying both remains to be resolved. Meanwhile, a historical investigation into the status of the art-object as a distinctive category might be useful in this brief inquiry.

\section{Schematizing the beautiful}

Foregoing a complete history of the origin of aesthetics from classical antiquity up to the Renaissance, we may begin with
German philosophical idealism. Aesthetics (from the Greek aisthesis, "perception, sensation"), aesthetics was first theorized by Alexander G. Baumgarten in 1750 as "the science of sensory knowledge or cognition," whose aim is beauty, not truth. It was later elaborated by Kant as "the science of the rules of sensibility in general" concerned with the a priori principles of sensible experience. In Thomistic aesthetics, the intuitive knowledge of the sensible is grounded in intellectual judgment as knowledge of the universal. The artistic criteria of integritas, consonantia, and claritas are abstract ideas mediating the comprehension of the sensibles. ${ }^{3}$

In his Critique of Judgment (1790), Kant posited aesthetics as involved with the subjective feeling of pleasure and pain, hence aesthetic judgments pertain to the subject, not the object represented. What is beautiful is tied with disinterested pleasure, a judgment of taste based on immediate intuition without a concept. Kant argues that "Beauty is the formal aspect of purposiveness, insofar as it is perceived in the objectified without the representation of purpose... [T] hat which is generally pleasing, without a concept, is beautiful". ${ }^{4}$ Formal purposiveness without purpose--this axiom established the privileged autonomy of art which prevailed up to Clement Greenberg's pontifications on abstract expressionism.

Two additions to Kant may be cited here. First, Schelling proposed the romantic theme of beauty as "the Infinite infinitely presented," while Hegel is said to have summed up the classic traditional thinking in his view that Beauty equals Idea, beauty as the sensuous manifestation of the Idea. However, the beautiful is nothing unless it is externalized or mediated in the work of art in which the beholder and the artist's mind encounter each other. The idea then is the content of the art-work in its dynamic historical evolution. In the nineteenth century, the psychological approach dominated the investigations of Schopenhauer, Nietzsche, Herbart and Fechner, the latter inaugurating the empirical-experimental approach to aesthetics. This was followed by Theodor Lipps notion of empathy, with esthetic enjoyment conceived as "objectivized self-enjoyment," an inner imitation of artistic creation. With Benedetto Croce, this idealist line of speculation 
culminates in art as intuitive activity, an expression of inwardness, eluding the screen of formal mediation.

Hegel emphasized the philosophical function of art as a vehicle of reason in quest of universals realized in history. While Hegel believed art to furnish "the sensuous semblance of the idea," for Croce, universals and history disappear. Croce reduces art to lyrical intuition, separated from the phenomenal contingent world, pure intuition whose modes of expression exist in the artist's mind. The actualization of this intuition is secondary; expression and communication do not affect the value of the unreflected intuition. Unconcerned with the play of imagination or the immediacies of feeling, Croce absolutized intuition as a complex blend of idea, image and expression whose singularity, however, resists philosophical generalization. ${ }^{5}$ Croce's expression theory complements the formalist stress on essential form in Clive Bell, Roger Fry, I.A. Richards, and their American counterparts in the New Criticism. Whether the naturalism of John Dewey's theory of art as intense experience can be reconciled with Croce, is still a debatable proposition.

Aesthetics as an inquiry into normative concepts and values regarding beauty may have given way to modern interest in a descriptive and factual approach to the phenomena of art (production and reception) and aesthetic experience. Beauty is now construed as an effect of form, of discursive signifying practice. One can mention Charles Morris' idea of art as iconic symbol of value, as well as Susanne Langer's conception of art is the symbol or expressive form whereby emotions are rendered apprehensible in their formal embodiments or styles. Aside from the phenomenological approach deployed by Martin Heidegger, Sartre, Merleau-Ponty and others, the dominant aesthetic stance in the United States for a long time has been exemplified by the eclectic Journal of Aesthetics and Art Criticism which welcomes all forms of scientific, descriptive, or criticalhistorical treatment of questions concerning art.

\section{Historicizing form}

Together with beauty and the sublime, the ideal of autonomy and artistic genius dissolved with the age of mechanical reproduction. Walter Benjamin dealt a fatal blow to the norm of authenticity; the Here and Now of the original is constantly being destroyed by capitalism. Besides the formal properties that authenticate the artwork, the contents of art (idealistic content-aesthetics) have suffered the impact of contingency, chance or accident, entropy, the inexorable incursions of the unpredictable. Art is not timeless but changeable, subject to the process of becoming. Hegel's "bad conscience" implies that art is never for itself but requires, in fact demands, the exegesis and interpretation of others outside the artist. Art's truth-content cannot be fully exhausted by any single hermeneutic organon. Since interpretations are open and endless, all art is subject to historicity and the mutability of standards and criteria of judgment.

In this new catastrophic period of triumphalist globalism, the issue of materialist aesthetics appears not only anachronistic but also a perverse joke. Except those fashioned for immediate use-value (for therapy, etc.), all art in capitalism has become a commodity (exchangevalue). And since Marxist revolutionaries have become obsolete if not rare today, aesthetics has become the preserve of museum curators, academic experts/shamans, and theologians attached to art galleries and auction houses. Except for Terry Eagleton, Fredric Jameson, John Berger, and the late Polish philosopher Stefan Morawski ${ }^{6}$ no serious Marxist thinker has devoted a wholesale engagement with the theory of art, with aesthetic criticism and inquiry.
Indeed, in a 1983 international conference on "Marxism and the Interpretation of Culture," Michelle Barrett ${ }^{7}$ bewailed the lack of adequate discussion of aesthetic pleasure and value. Given the vogue of poststructuralist textualism and postmodernist nominal's, aesthetics was overshadowed by or subsumed in discourses on ideology, representation, and the deconstruction of the subject. Nature and objective reality have been cancelled out to give room to the floating signifier, difference, aporia and contingency. Henceforth the "free play" of the liberated signifier would call the shots. Subjectivity, or subject-positions, becomes reduced to simulacra, aporia, or undecidables vulnerable to infinite semiosis, that is, interminable sequence of interpretations. But this chaos did not discourage Barrett from giving self-confident judgments. She nonchalantly dismissed vulgar concerns about art's "truth" and social relevance because the meanings of art works are not imminent but constructed "in the consumption of the work" $(1988,702)$. Readers/spectators actively co-create the meaning and significance of the art-work. Contrary to the orthodox ideas about typical characters and organic form, Barrett holds that ideological content and political implications are not given in the art-work but are effects or constructions by readers/audiences, an assertion justified within the framework of a reader-response/ reception aesthetics. This position is clearly symptomatic of the move of Barrett's cohort toward a more open-ended, adventurist, innovative stance, rejecting not only reflectionist theory ${ }^{8}$ but also interventionist approaches. ${ }^{9}$ But what exactly do we mean by a Marxist approach to aesthetics or theory of art?

\section{Revisiting marxist aesthetics}

In the wake of the post-structuralist transvaluation of texts as the ceaseless play of differance, of the unchoreographable dance of signifiers, which one may interpret as a historically specific reaction in the Western milieu to dogmatist leftism in its various manifestationseconomistic, sectarian, mechanical, empiricist, etc. I would like to reaffirm once more the occluded yet irrepressible matrix of art in the Marxist concept of praxis and political struggle. Enunciated by Marx in Theses on Feuerbach and The Eighteenth Brumaire in particular, this inscription of the aesthetic in transformative action I would call the "Leninist moment," the hegemonic or ethico-political crux in Marxist critical theory. In The Aesthetic Dimension, Herbert Marcuse ${ }^{10}$ attempts to posit and validate the crucial divorce between aesthetics and politics in late monopoly capitalism by suggesting that Lenin, and the Bolshevik revolutionary tradition originating from Marxism-Leninism, rejected the transcendental and liberating "truth of art" (1978, 56-57). From within a revisionist perspective the Polish aesthetician Stefan Morawski distorts Lenin's dialectical conception of art by defining it as narrowly concerned with "the popularization of culture," and guilty of "Utilitarianism" (1974, 261). Even for the sophisticated British critic Terry Eagleton, Lenin's "epistemological theory of reflection" generates more problems than it solves. In sum, the putative reflection theory ascribed to Lenin and orthodox Marxists has become the favorite whipping horse of bourgeois theoreticians ranging from academic Marxologists like Peter Demetz ${ }^{11}$ to liberal commentators like Edmund Wilson ${ }^{12}$ and George Steiner. ${ }^{13}$

\section{Lessons from lenin}

With the renaissance of Marxist critical theory in the late Sixties, especially the recovery of certain fundamental insights into the constitution of the subject by ideology facilitated by Althusser's "structuralist readings," it seems appropriate to re-situate the necessary task of Marxist critical theory on artistic production within 
a revolutionary dialectical strategy of cultural politics. This strategy would not simply be a deconstructive scholastic reading of texts to disclose their metaphysical fallacies or rhetorical virtues, a practice inspired by leftist followers of Derrida and Foucault. It would also not be a revival of a utopian or prophetic strain in Marxism as an alternative to bureaucratic conservatism or social-democratic opportunism, an approach exemplified by Maynard Solomon's instructive anthology. ${ }^{14}$ What this strategy hopes to encourage is the active intervention of the critic or theoretician in the social practices of everyday life. In Lenin's critical practice of deciphering texts, particularly in his appraisal of Tolstoy's works, we can discern the model of an interrogatory hermeneutic praxis. Lenin focuses on the organic yet mediated linkage between knowledge and action, cognition and organized will-a new radical conception of textuality and signifying practice which would be elaborated later on by Christopher Caudwell, ${ }^{15}$ deepened by Antonio Gramsci, 8 and actualized by the Lehrstucke of Bertolt Brecht. ${ }^{16}$

As Pierre Machere ${ }^{17}$ has pointed out in his A Theory of Literary Production (1966), Lenin demonstrated the internal contradictions in Tolstoy's writings between the critical-realistic protest embodied in the texts and the quietist reactionary doctrines thematized by the allegorizing tendencies in narrative. He pointed out how these contradictions spring from the ideological position of the artist himself and the inherent limitations of such a position. While defining the limits of his ideology through narrative form, Tolstoy's art distances itself from its intrinsic ideology by foregrounding the principle of conflict. Such distancing or decentering opens up the space for critical intervention, an opening seized by Lenin. This can be illustrated by Lenin ${ }^{18}$ remark in "Leo Tolstoy as the Mirror of the Russian Revolution"(1908): "But the contradictions in Tolstoy's views and doctrines are not accidental; they express the contradictory conditions of Russian life in the last third of the nineteenth century. The patriarchal countryside, only recently emancipated from serfdom, was literally given over to the capitalist and the tax collector to be fleeced and plundered...”(1967, 30). Tolstoy's views, Lenin urged, should be appraised from the standpoint of democratic protest against advancing capitalism, a protest embodied in non-violent religious language permeating the consciousness of Russian peasants and landlords "at the time the bourgeois revolution was approaching mankind." Further, "Tolstoy is original, because the sum total of his views, taken as a whole, happens to express the specific features of our revolution as a peasant bourgeois revolution" (1967, 30; also 48-62).

Tolstoy's landlord/patriarchal ideology, characterized by a sharp awareness of conjunctural class conflict and a specific resolution proposed for this conflict, finds itself objectified and interrogated by the structure of his texts which metamorphoses illusions (enabled by ideology) into visible objects and practices. In this process, the ideology is internally displaced or redoubled, thereby exposing its limits and inadequacies (for example, the social framework of beliefs informing the protagonists in Anna Karenina). For these limits, silences or absences to reveal their presence, a dialectical reading is required. In Lenin's reading, we see the analysis of the historical contradictions in Tolstoy's class position vis-a-vis the 1905 bourgeois democratic revolution manifest as the preaching of Christian quietism, an ethico-political position which hides the complex totality of the material contradictions. In the same breath, the intrinsic lack in the text expresses the historical deficiency or insufficiency of the historical situation, namely, the ambiguous role of the peasantry in the emerging socialist revolution. One can perceive this problematic of Tolstoy's ideology being interrogated and demystified (its false claims to totality and naturalness exposed) in a narrative like "The Death of Ivan Ilyich" where the existential anguish suffered by Ivan exceeds the social corruption afflicting his petty bourgeois stratum. At the same time, his predicament erases the subjectivities of women and the servant Gerasim-not erases but rather neutralizes them in conformity with the pietist or moralizing closure of the text.

\section{Symptomatic beginnings}

While the symptomatic diagnosis which Macherey ${ }^{17}$ recommends tends to privilege the text as a displacing mechanism that reveals the incongruities and dissonances marking the limits of ideological incorporation, I would like to stress here that Lenin's own critical practice operates within and outside the text-bound, purely hermeneutical method. By situating Tolstoy's texts at the conjuncture of class alignments (Gramsci's relation of historic forces) and focusing on the problematic role of the peasantry in the revolutionary process as a whole, Lenin anatomizes the contingencies of literary form itself. In other words, the text is articulated by multiple determinations, not just by the purely linguistic or rhetorical. In effect Lenin decentered the organic formal unity of texts, elucidating their "political unconscious" $" 16$ in the conflicted historical totality subsuming them.

This argument concerning the textual production of meaning, the discursive process of signification as a dialectical transaction in which ideology is cognized as a social practice, not a transcribed "false consciousness," is not Lenin's innovation--his intervention takes the form of articulating a conjunctural theory of revolutionary strategy and tactics outlined in what is to be done? It is actually Marx's, specifically in his critique of religion where the notion of what Lukacs later on calls "reification" as derived from commodity-fetishism is first formulated. ${ }^{18}$ In general, religion as an "inverted worldconsciousness" provides the heuristic model for the unity-in-conflict of the real and the illusory. Marx ${ }^{19}$ associates praxis with discourse in The German Ideology and in his critique of Hegel's Philosophy of Right:

Religion is, in fact, the self-consciousness and self-esteem of man who has either not yet gained himself or has lost himself again....It is the fantastic realization of the human being because the human being has attained no true reality....The wretchedness of religion is at once an expression of and a protest against real wretchedness. Religion is the sigh of the oppressed creature, the heart of a heartless world and the soul of soulless conditions. It is the opium of the people. The abolition of religion as the illusory happiness of the people is a demand for their true happiness. The call to abandon illusions about their conditions is the call to abandon a condition which requires illusions. Thus, the critique of religion is the critique in embryo of the vale of tears of which religion is the halo...Here Marx grasps the superstructure (religion) not as epiphenomena but as an integral element of an all pervasive social practice. In conceptualizing the contradictory relation between intellectual objectification and social reality, Marx laid the groundwork for the active, dynamic and creative intervention of transformative agents. Such agency, relative to varying historical sites, can be instanced by Lenin's bolshevik party, Gramsci's "organic intellectuals" functioning in the ideological apparatuses of civil society. Or it can assume the guise of Brecht's avant-garde epic gesture aimed at destroying the habit of organic idealist thinking and its roots in the Kantian fetishism of categories. ${ }^{20}$

\section{Interventions by caudwell}

It would also be instructive to review here Christopher Caudwell ${ }^{15}$ argument in Illusion and Reality (1937) that poetry, art in general, 
is a specific mode of production of "historically necessary forms of social consciousness," in short, of literature as politically defined signifying practice. Caudwell's controlling insight that the concept of bourgeois freedom is premised on the ignorance of social relations-an instance of the working of commodity-fetishism--stems from his thesis of the dialectical unity of subject and object. This thesis is an epistemological axiom implied in Marx's concept of the subject as sensuous-practical activity, "theory as the outcome of practice on the object". Marxist theory is oriented toward "concrete living," toward the realization of freedom (development or fulfillment of man's species-being) by society, collective or associated producers, mastering and directing the forces of nature. Engels conceived of freedom as lived in the appreciation of the necessary inscription of humans in nature and society. What is relevant for us in this context is Caudwell's articulation of the aesthetic function, his view that art is not just a mere transcription of subjectivity (as in formalist idealism) nor a representation of objective reality (as in mimetic naturalism) but a production of a "mock world" where the "I," the transindividual subject of culturally determinate discourse (not the self-present "I" of phenomenology)-the "I" as a socially constituted ego of the "common affective world"--actualizes itself in comprehending and transforming the real world. "Poetry is...the sweat of man's struggle with Nature" conducted in history: "the phantasy of poetry is a social image". ${ }^{21,22}$

\section{Brecht's scenario}

It remained for Brecht, in his decisive contestation with Lukacs in the Thirties over the methodology for achieving the goal of socialist realism, to elucidate not so much the objective moment-the historicity of phenomena, commodities as frozen or "dead" labor; life as "human sensuous activity" or praxis--as the subject moment or pole of the dialectic. In the context of a historical materialism challenged by fascist violence, Brecht theorized the mental and perceptual categories through which, in the art-work and in the audience, the social totality is mediated and the opportunity for action drawn. In the meantime, the mode of nineteenth-century realism valorized by Plekhanov, Mehring and early Marxist critics prevented the exploration of other alternatives to register the subtle mutations of middle-class consciousness in the post-World War I era. How can a revolutionary practice of writing combat the lure of bourgeois ideology and what Lukacs calls "reification" if it employs the mode of classic expressive realism? The tendency of such realism is precisely to conceal the historical specificity of the production of meaning and the realityeffect of prevailing codes of representation. Realism generates the notion of a subject as a given presence without history, self-identical, free and homogeneous: the bourgeois illusion Caudwell tried to exorcise. If subjectivity is a discursive construct, as Caudwell may be read to imply, and the forms of discourse vary relative to specific formations and class positions, then the key to producing politically effective art lies in a critical/creative practice where the signifying process is fore grounded and interrogated. Is the code of realism itself an immutable formal criterion? Or are the means of unfolding social totality and enabling access to it a matter of conventions determined by concrete historical conjunctures-the convergence of ideological, political and economic instances to which Althusser called attention? Is there just one realist style or form? Or is realism the epistemological and cognitive perspective within which a variety of forms (semiotic styles, signifying practices) can operate? While it is obligatory to contextualize the famous Lukacs ${ }^{23}$ debate in order to account for Lukacs' privileging of the "intensive totality" of critical realism (evinced in Thomas Mann) and Aristotelian catharsis, ${ }^{9}$ and for Brecht's dialectical conceptualizing of realism, it would be instructive to rehearse the nodal theoretical points in this exchange. At the outset, I would express my partiality for Brecht's arguments in the light of my commitment to Third World anti-imperialist struggles where aesthetic problems and cultural tasks are over determined by strategic political needs. On the other hand, my work on Lukacs San Juan ${ }^{14}$ testifies to his enduring value as a heuristic guide to renewing the immense creative potential of Marxism in a time when the old paradigms and formulas can no longer elucidate postmodern reality. Precisely in focusing on contradiction as the dynamic motivation behind any materialist theory of reflection, Brecht rejects the contemplative and utopian (in the pejorative sense) thrust of Lukacs' cognitive rationalism. ${ }^{19}$ Brecht follows Lenin in situating the text (literary form, technique, genre) within the practical exigences of the class struggle. In a totalizing view, he takes "into account the degree of education and the class background of their public as well as the condition of the class conflicts". 21,22

While the contemporary poststructuralist critic may discount Brecht's preoccupation with alienation-effect as merely an offshoot of his project of unfolding the causal nexus, "the network of social relationships," constituting any event, Brecht cannot be classified simply as an exponent of "epistemological conventionalism." He certainly does not subscribe to the tenet of the undecidability of meaning premised on the alleged disappearance of the referent. Brecht's aesthetics includes a rhetorical or pragmatic moment within the cognitive: because what is represented in theater is not empirical montage of phenomena but the laws of social motion, to accomplish this task successfully it is necessary to enforce a critical distance, to remove the plausible and familiar elements in life which hide the possibilities for change in the nexus of events and actors. ${ }^{23}$ The knowledge induced by this syncopated or stylized realism involves the recipient's perception of such possibilities, a perception indistinguishable from a learning process where pleasure coincides with the critical questioning of reality. This critical response entails a desire to play or experiment and thus transform the given situation according to the dictates of the "collective phantasy," to use Caudwell's evocative phrase..$^{13}$ It is clear that Brecht's overriding purpose is to mobilize individual energies for collective intervention in changing society, a goal to which the choice of forms or technical means is subordinate. Revealing the historicity of social relations, disclosing forms and ideas as constructs informed by alterity and difference, requires the will to subvert one-dimensional homogenizing thought. It implies the production of meaning through the act of demythologizing public consensus and demystifying received norms. Historicizing texts--making visible the dynamics of ideological production in shaping them--demonstrates and confirms the capacity of humans to collectively shape their world and realize man's unique species-being. Brecht's materialism re-inscribes the reader or spectator as potential revolutionary agency in the interstices of a conflicted totality, a society in process of change.

In an article dated 12 August 1953, "Cultural Policy and Academy of Arts," Brecht reiterates his demand for art's "broad intelligibility," its harnessing of the progressive elements in a national tradition, and its project of socialist realism as "a deeply human, earth-oriented art which will liberate every human capacity." Polemicizing against dogmatic and bureaucratic pontifications issued by party officials, Brecht summed up his conception of socialist realism with which I am broadly in agreement. Socialist realism embraces two central themes: first, socialist realist works reveal characters and events as contradictory, historical and alterable, laying bare "the dialectical laws of movement of the social mechanism" so that the "mastering 
of man's fate" is made easier; and second, socialist realist works provoke "pleasure at the possibility of society's mastering man's fate," pleasure confluent with "socialist impulses." Underlying this second proposition is the primacy of a working-class viewpoint that strives "to raise human productivity to an undreamt-of extent by transforming society and abolishing exploitation". ${ }^{24}$

What Brecht adds to Caudwell's notion of the genotype (the collective impulse of human desire) and to Lukacs' axiom of typicality is a more thorough dialectical grasp of dissonance or conflict as the driving force behind social processes (see in particular number 45 of "A Short Organon for the Theater"). He also exhibits an unprecedented emphasis on socially shared pleasure which transposes the utopian or prophetic vision that Bloch \& Benjamin ${ }^{25}$ appreciated in Marx--the "becoming" and "disappearance" of contradictions--into a sensuous, "earthly" performance. Brecht seems to re-articulate in his own language Lenin's hermeneutic discovery of the lacunae and discrepancies in Tolstoy's texts when Brecht foregrounds the pleasureyielding effect of learning solidarity and struggle, as suggested in the concluding passage of his "Organon": our representations must take second place to what is represented, men's life together in society; and the pleasure felt in their perfection must be converted into the higher pleasure felt when the rules emerging from this life in society are treated as imperfect and provisional. In this way the theater leaves its spectators productively disposed even after the spectacle is over. Let us hope that their theatre may allow them to enjoy as entertainment that terrible and never-ending labor which should ensure their maintenance, together with the terror of their unceasing transformation. Let them here produce their own lives in the simplest way, for the simplest way of living is in art. ${ }^{13,26}$

The antinomies of form and content, style and theme, the popular and the realistic qualities in art-works, which took center stage in the debate between Lukacs and Brecht in the Thirties, can be traced in the fractured and unresolved texts of Marxist cultural politics--from Trotsky's Literature and Revolution (1936) to Mao's influential Talks at the Yenan Forum on Literature and Art (1942). Questions about which has primacy--form or content, authorial will or audience reception, political correctness or technical efficacy--can perhaps be clarified by examining next Gramsci's theory of hegemony as a political-ideological strategy founded on a recovery of the authentic Marxist conception of praxis. ${ }^{7}$

Let us recall that in Theses on Feuerbach Marx not only stressed the centrality of "human sensuous activity, practice," which defines the substance of social life; he also pointed out that "the human essence is not an abstraction inherent in each single individual" but is in fact indivisible from "the ensemble of social relations." Further Marx underscored in Thesis X that "the standpoint of the old materialism is civil society; the standpoint of the new is human society, or socialized humanity." Contrary to the one-sided culturalist reading of Gramsci's thought which privileges the sphere of ideology outside the political, I submit that the site of hegemony is not just civil society but the totality of social relations where production and the state, economic base and ideological superstructure, constitute an ongoing process of changing power relations: class subordination and dominance. ${ }^{27}$

\section{Gramsci's reminders}

The problem of conceptual art as the reinscription of immediacy via disursive practice involves the position of the artist in hegemonic society, Gramsci may provide a useful analytic optic in elucidating this issue. By contextualizing the individual artist in a historically specific milieu, Gramsci qualifies all aesthetic questions as ultimately political in character insofar as they are inscribed in culture grasped as a lived process of experience, not an abstract or simply functional institution. Raymond Williams provides us with the most precise description of what in Gramsci involves a whole range of ethico-political activities. For Williams, the hegemony of posmodernist art should be comprehended as "a whole body of practices and expectations, over the whole of living: our senses and assignments of energy, our shaping perceptions of ourselves and our world. It is a lived system of meanings and values-constitutive and constituting--which as they are experienced as practices appear as reciprocally confirming. ${ }^{28}$

From this point it is only a short step to reconceptualizing the dialectical linkage between form and content in conceptual art by their thorough historical grounding in specific conjunctures. The metaphysical problematic of Kant, Hegel and Croce is thereby displaced or re-situated in concrete social predicaments. Gramsci contends for a dialectical interpretation of the polarity: "Can one speak of a priority of content over form? One can in this sense: the work of art is a process and changes of content are also changes of form....Therefore, 'form' and 'content' have a 'historical' meaning besides an 'aesthetic' one. 'Historical' form means a specific language, just as 'content' indicates a specific way of thinking that is not only historical...". ${ }^{29}$

What unfolds in Gramsci's reflection is a materialist contextualization of the content-form duality in a process of discursive production: "historical form signifies a determinate language, while 'content' signifies a determinate way of thinking". For Gramsci, then, the objectification or historicization of what is imagined (phantasy activity, for Caudwell) not only proceeds in the mind but, more decisively, coincides with the "forming" process (poiesis, in Greek) which necessarily operates with material, sensorily apprehensible media, channels, devices, etc. ${ }^{30}$ Not only are forms of thinking already structured by socially determinate values, but forms of expression or representation are also given beforehand, that is, before creative appropriation begins. This is because techniques and other linguistic or formal elements are not pure schemata or empty categories but are in fact constituted by functional, culture-bound semantic values. In short, form is ideological in essence and thus political in its wider implication. For Gramsci, however, content is not the experience but the writer's attitude to it, an attitude which ultimately shapes style: "...'technical' stands for the means by which the moral content, the moral conflict of the novel, the poem, or the drama is made comprehensible in the most immediate and dramatic way possible".

Gramsci historicized the Kantian "beautiful" in the concrete conctradictions of society: "The battlefield for the creation of a new civilization is...absolutely mysterious, absolutely characterized by the unforeseeable and the unexpected. Having passed from capitalist power to workers' power, the factory will continue to produce the same material things that it produces today. But in what way and under what forms will poetry, drama, the novel, music, painting and moral and linguistic works be born? It is not a material factory that produces these works. It cannot be reorganized by a workers' power according to a plan. One cannot establish its rate of production for the satisfaction of immediate needs, to be controlled and determined statistically. Nothing in this field is foreseeable except for this general hypothesis: there will be a proletarian culture (a civilization) totally different from the bourgeois one and in this field too class distinctions will be shattered.... The Futurists [in our time, the conceptualists or postmodernists] have carried out this task in the field of bourgeois 
culture.... $^{31,32}$ [The Futurists] have grasped sharply and clearly that our age, the age of big industry, of the large proletarian city and of intense and tumultuous life, was in need of new forms of art, philosophy, behavior and language. This sharply revolutionary and absolutely Marxist idea came to them when the Socialists were not even vaguely interested in such a question.... In their field, the field of culture, the Futurists are revolutionaries. ${ }^{9}$

\section{Prelude to a postscript}

One conclusion emerges from this brief survey of the nodal stages in the vicissitudes of Marxist critical theorizing on the politics of aesthetics: without the focus on the moment of praxis-the artist's or critic's intervention in the concrete arena of political struggle for hegemony, any reflection on the nature of art and its function will compulsively repeat the metaphysical idealism (Kant, Hegel, Croce) it seeks to overcome. ${ }^{33}$ It is in the arena of political and ideological conflict that consciousness is grasped in its over determined trajectory as a complex of material practices functioning in conserving or distintegrating a determinate conjuncture, a lived situation. Without positing this moment of rupture or opening for intervention, we shall reproduce the predicament of the bourgeois intellectual which Caudwell and Lukacs (in History and Class Consciousness) acutely diagnosed: the division of mental and manual labor; the antinomy between subject and object, society and individual, nature and history, which revolutionary socialist practice hopes to gradually and eventually resolve, despite setbacks and mistakes in the itinerary of struggle Robert Tucker. ${ }^{34}$

One way of blocking this compulsion to repeat mechanical or essentializing practices is to compose a totalizing, more or less coherent narrative, a space (cognitive and pragmatic at the same time) where values/meanings compete; where a kind of Marxist selfrecognition of its authentic vision may crystallize in the struggle of antagonistic interpretations consonant with the concrete ideological problems ushered by the era of glasnost and the collapse of "actually existing socialism" in Eastern Europe. ${ }^{35-37}$ Such a task commands priority in the agenda of progressive intellectuals everywhere.

\section{Acknowledgments}

None.

\section{Conflicts of interest}

The author declares that there is no conflict of interest.

\section{References}

1. Godfrey Tony. Conceptual Art. London: Phaidon; 1988. 448 p.

2. Bothamley Jennifer. Dictionary of Theories. London: Gale Research International Ltd; 1993. 637 p.

3. Eco Umberto. The Aesthetics of Thomas Aquinas. Cambridge, MA: Harvard University Press; 1988. 302 p.

4. Guttmann James. Philosophy A to Z. New York: Grosset \& Dunlap; 1963. $272 \mathrm{p}$.

5. Richter, David H. 1994. Croce, Benedetto. The Johns Hopkins Guide to Literary Theory and Criticism. Baltimore and London: The Johns Hopkins University Press; 1994. 1008 p.

6. Morawski Stefan. Inquiries into the Fundamentals of Aesthetics. Cambridge, Mass: MIT; 1974. 426 p.
7. Barrett Michele. 1988. The Place of Aesthetics in Marxist Criticism. In: Lawrence Grossberg, Cary Nelson, editors. Marxism and the Interpretation of Culture. Urbana, IL: University of Illinois Press; 1988. $738 \mathrm{p}$.

8. Gramsci Antonio. The Modern Prince and Other Writings. New York: International; 1957. $192 \mathrm{p}$.

9. Lukacs Georg. Essays on Realism. Cambridge, Mass: MIT; 1980. 256 p.

10. Marcuse Herbert. The Aesthetic Dimension. Boston: Beacon; 1978. 400 p.

11. Demetz Peter. Marx, Engels and the Poets. Chicago: University of Chicago Press; 1965. 278 p.

12. Wilson Edmund. The Triple Thinkers. New York: Harcourt; 1948. 284 p.

13. Georg Lukács. History and Class Consciousness. London: Merlin; 1971. $356 \mathrm{p}$.

14. San Juan E. Marxism and Human Liberation Essays by Georg Lukacs. New York: Delta; 1973. 332 p.

15. Caudwell, Christopher. Illusion and Reality. New York: International; 1937.

16. Brecht Bertolt. On Theater. New York: Hill \& Wang; 1964. 294 p.

17. Macherey Pierre. A Theory of Literary Production. London: Routledge; 1978. $400 \mathrm{p}$

18. Lenin VI. On Literature and Art. Moscow: Progress; 1976. 185 p.

19. Jameson Fredric. Marxism and Form. Princeton: Princeton University; $1971.432 \mathrm{p}$.

20. Marx Karl. Critique of Hegel's Philosophy of Right. In: Joseph O'Malley, editor. Chicago: University of Chicago Press; 1970. 151 p.

21. Duparc Jean, David Margolies. Christopher Caudwell Scenes and Actions. London: Routledge; 1986. 241 p.

22. Margolies David N. The Function of Literature. New York: International; 1969. 228 p.

23. Mittenzwei Werner. The Brecht-Lukacs Debate. In: Ursula Beitz, Gaylord Leroy, editors. Preserve and Create. New York: Humanities; 1973. 366 p.

24. Lang Berel, Forrest Williams. Marxism and Art. New York: Putnam; 1972.

25. Bloch, Ernst, et al. Aesthetics and Politics. London: Verso; 1997. 220 p.

26. Williams Raymond. Marxism and Literature. New York: Oxford; 1977. $224 \mathrm{p}$.

27. Arvon Henri. Marxist Esthetics. Ithaca: Cornell; 1973. 125 p.

28. Boelhower William. Antonio Gramsci's Sociology of Literature. Contemporary Literature. 1981;22(1):580-595.

29. George Moberg. Studies and Further Studies in a Dying Culture. New York: Monthly Review; 1971. 154 p.

30. Craig, David. Marxists on Literature. London: Penguin; 1975. 38 p.

31. David Forgacs Geoffrey, Nowell Smith. Selections from Cultural Writings. Cambridge, Mass: Harvard; 1985. 448 p.

32. Quentin Hoare, Geoffrey Nowell Smith. Selections from Prison Notebooks. New York: International; 1971. 846 p.

33. Arthur D Kahn. Writer and Critic. London: Merlin; 1970. 258 p.

34. Robert Tucker. The Marx Engels Reader. New York: Norton; 1978. 830 p. 
35. Mulhern Francis. The Marxist Aesthetics of Christopher Caudwell. New Left Review. 1974; 85(1):37-58.

36. Vogel, Carol. Grisly Warhol Painting Fetches \$104.5 Million, Auction High for Artist. NW: New York Times; 2013. 926 p.
37. Selsam Howard, Harry Martel. Reader in Marxist Philosophy. New York: International; 1963. 384 p. 